\title{
Light and transmission electron microscopy of generalized dystrophic epidermolysis bullosa (Pasini's albopapuloid subtype)
}

\author{
Microscopia óptica e eletrônica de transmissão da epidermólise bolhosa \\ distrófica generalizada (subtipo albo-papulóide de Pasini)
}

\author{
Hiram Larangeira de Almeida $\mathrm{Jr}^{1}$ \\ Nara Moreira Rocha ${ }^{3}$
}

\author{
Lísia Nudelmann ${ }^{2}$ \\ Luis Antonio Suita de Castro ${ }^{4}$
}

\begin{abstract}
Pasini's albopapuloid epidermolysis bullosa is a very rare subtype of generalized dystrophic dominant epidermolyis bullosa. A 30 year-old white female patient presented since her childhood disseminated small blisters and papules. Light microscopy of a blister showed dermal-epidermal cleavage; moreover, focal areas of dermal-epidermal splitting were also observed. Transmission electron microscopy also identified focal areas of cleavage, which were seen below the lamina densa. It is important to recognize this condition as a variant of epidermolysis bullosa, since the most important cutaneous findings are generalized papules and not blisters and erosions as in other forms of epidermolysis bullosa. Keywords: Epidermolysis bullosa dystrophica; Epidermolysis bullosa, junctional; Epidermolysis bullosa simplex; Histology; Microscopy, electron, transmission

Resumo: A epidermólise bolhosa albo-papulóide de Pasini é uma variante rara da forma generalizada de epidermólise bolhosa distrófica dominante. Uma paciente de 30 anos apresenta desde a infância pápulas e bolhas disseminadas. A microscopia óptica de uma bolha demonstrou clivagem dermo-epidérmica; além disso áreas focais de desprendimento dermo-epidérmico foram encontradas. A microscopia eletrônica de transmissão identificou a clivagem abaixo da lâmina densa. É importante que se reconheça essa variante de epidermólise bolhosa, já que o aspecto clínico predominante são pápulas disseminadas e não bolhas como nas outras formas de epidermólise bolhosa.

Palavras-chave: Epidermólise bolhosa distrófica; Epidermólise bolhosa juncional; Epidermólise bolhosa simples; Histologia; Microscopia eletrônica de transmissão
\end{abstract}

\section{INTRODUCTION}

Pasini's albopapuloid epidermolysis bullosa (PAP-EB), described in 1928, is a very rare subtype of generalized dystrophic dominant epidermolyis bullosa (DDEB). ${ }^{1-3}$ This group of EB has a cleavage under the lamina densa, due to dysfunction of the anchoring filaments. Very few cases were reported in the literature. ${ }^{4}$

\section{CASE REPORT}

A 30 year-old white female patient was examined in our outpatient clinic. She informed that since her childhood small blisters and papules appear on her skin. Some blisters are induced by trauma while others are spontaneous. Her older sister has similar cutaneous changes.

Skin examination showed disseminated whitish

Received on 01.12.2010.

Approved by the Advisory Board and accepted for publication on 01.02.2011

* Study carried out at the Catholic University of Pelotas (Universidade Católica de Pelotas - UCPEL), Universidade Federal de Pelotas (UFPEL) and Dermatology Service of Santa Casa De Misericórdia de Porto Alegre - Porto Alegre (RS), Brazil.

Conflict of interest: None

Financial funding: None

Lecturer - Assistant Professor, Universidade Federal de Pelotas (UFPEL) - Pelotas (RS), Brazil.

Dermatologist - enrolled in the Master's degree program, Pontifícia Universidade Católica do Rio Grande do Sul (PUC-RS) - Porto Alegre (RS), Brazil.

Biologist - Laboratory of Electronic Microscopy - Brazilian Agricultural Research Corporation, Center for Technical Production - Temperate Climate (EMBRAPA CPT - CT) - Pelotas (RS), Brazil.

Master's degree - Laboratory of Electronic Microscopy - Brazilian Agricultural Research Corporation, Center for Technical Production - Temperate Climate (EMBRAPA CPT - CT) - Pelotas (RS), Brazil. 
papules, which measured a few millimeters. Parallel to these papules a few erosions with hemorrhagic crusts were also observed (Figures 1A and 1B). She presented normal nails, teeth and hairs.

Under light microscopy a dermal-epidermal cleavage was easily identified (Figure 2A). With higher magnification it could be seen that the whitish papules corresponded to superficial dermal elevations, which had higher cellularity and sparse collagen, not arranged in bundles, when compared to the adjacent dermis (Figures 2B and 2C). Scattered in the specimen focal areas of dermal-epidermal splitting were also observed (Figures 3A and 3B). Staining for elastic fibers revealed their absence in these dermal elevations.

Transmission electron microscopy also identified focal areas of cleavage, which were seen below the lamina densa (Figure $4 \mathrm{~A}$ and $\mathrm{B}$ ). The dermis beneath the cleavage was formed by loose collagen fibers, which were not forming bundles and by an amorphous material (Figure 4C).
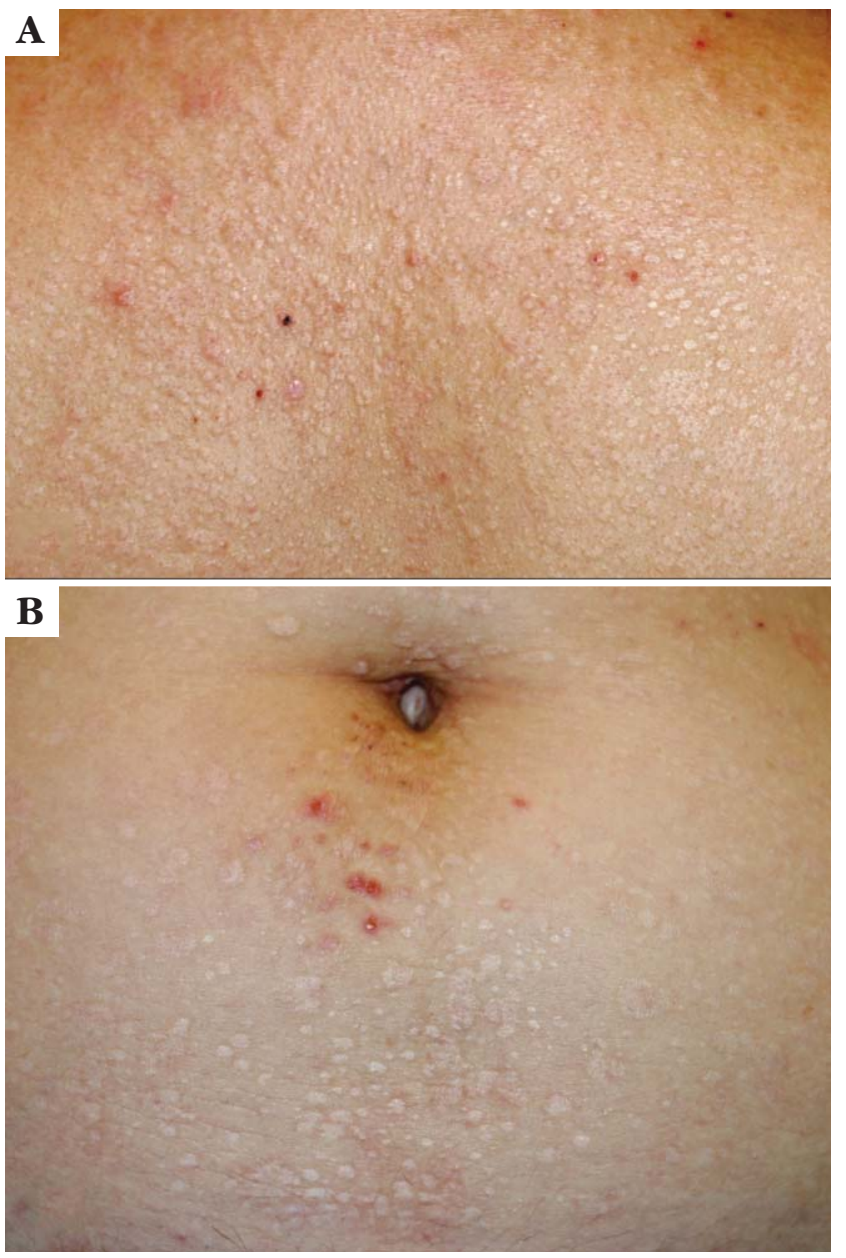

FIGURE 1: Whitish papules and hemorrhagic crusts in the interscapular (a) and periumbilical region (b)
$\mathbf{A}$
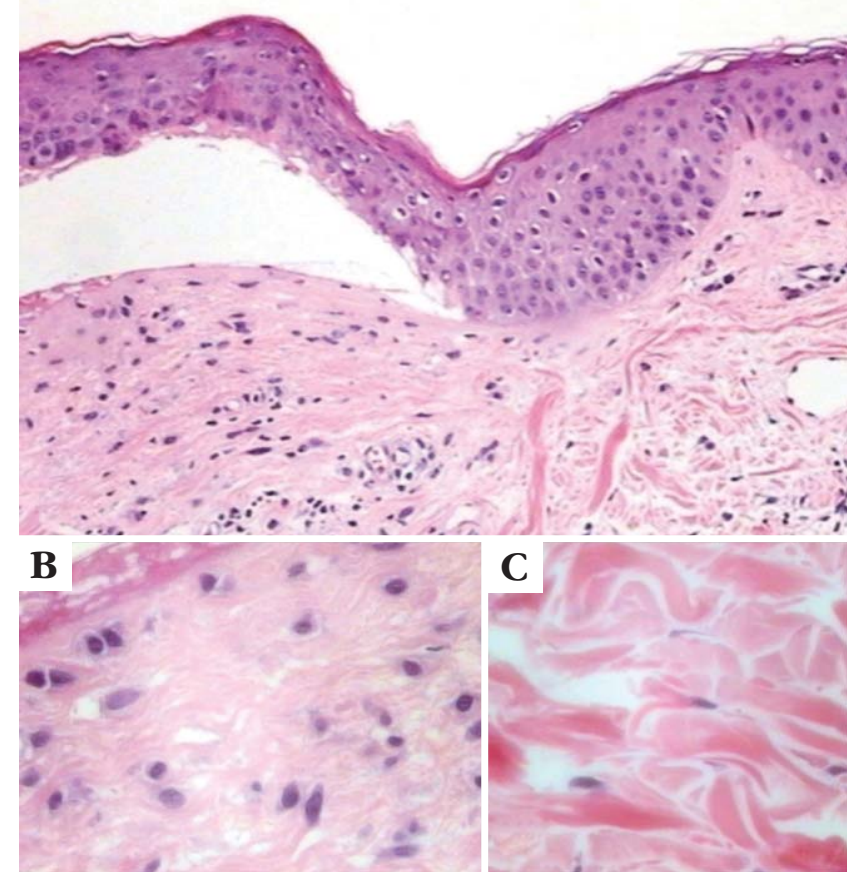

FIGURE 2: Light microscopy: a. dermal-epidermal cleavage (HE $x$ 100). b. detail of the papule with high cellularity and collagen fibers that do not form bundles (HE x400). c. normal adjacent dermis with collagen bundles

\section{DISCUSSION}

DDEB is caused by mutations in the COL7A1 gene leading to dysfunction of the anchoring filaments, differently from the recessive group, in which the absence of collagen VII leads to severe clinical features. ${ }^{5-7}$ Pasini's albopapuloid subtype belongs to the Generalized Dystrophic subgroup, and is characterized by disseminated whitish papules associated with blisters and erosions, as seen in this case. ${ }^{8}$ Nail and mucosal involvement is possible, not found in this patient.
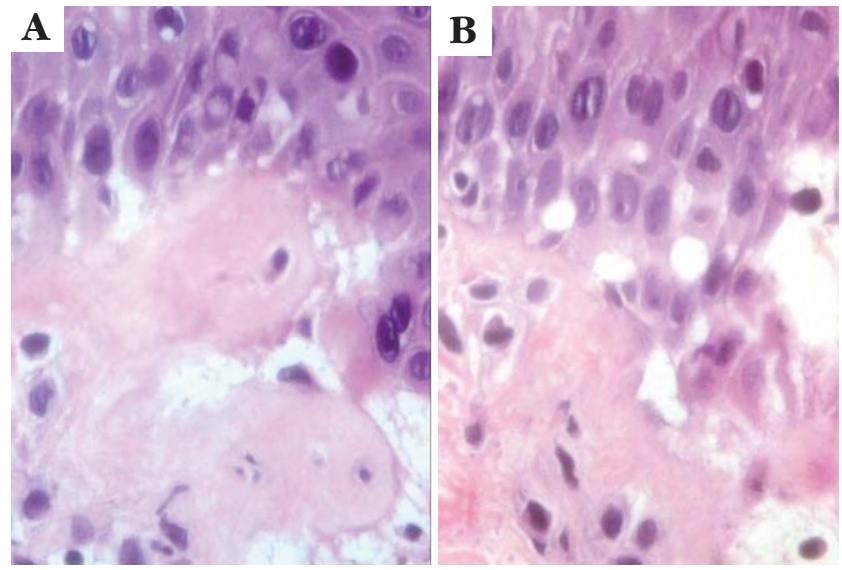

Figure 3: Light microscopy: $a$. and b. focal dermal-epidermal cleavage (HE x 400) 

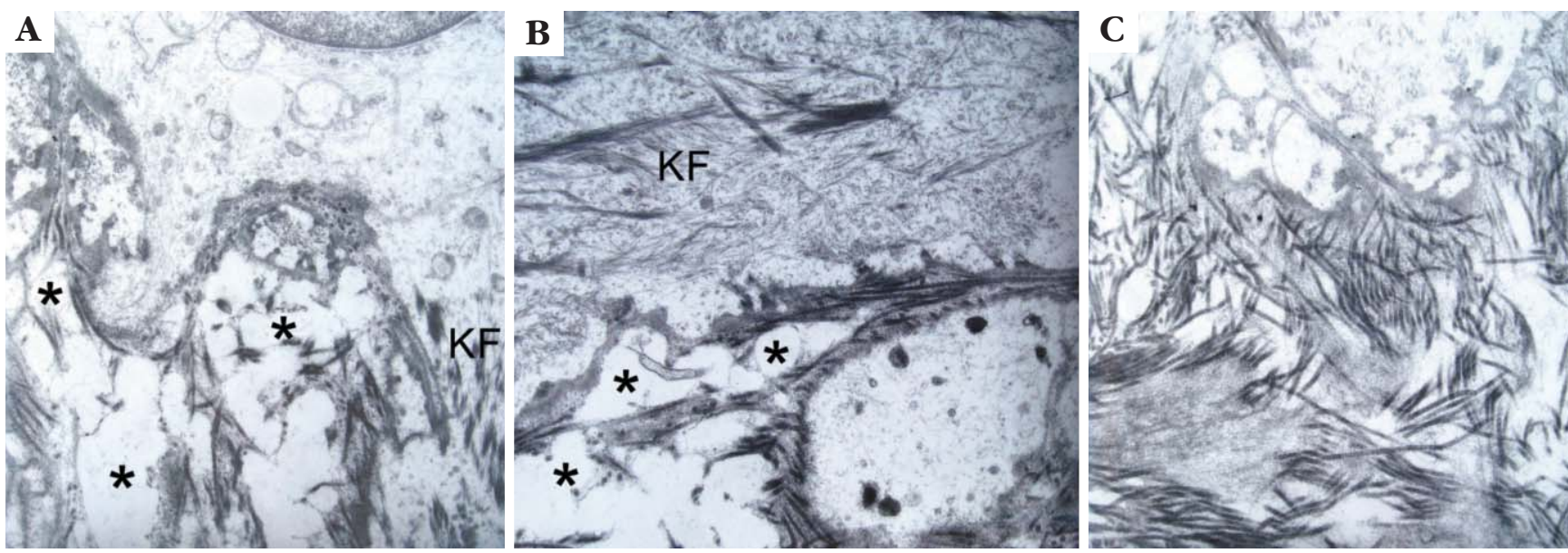

Figure 4: Transmission electron microscopy: a. and b. dermal cleavage (asterisks) under the lamina densa (KF - keratin filaments) (x 12.000) $\mathrm{c}$. isolated collagen fibers and deposition of amorphous material in the albopapuloid lesion(x 12.000)

With light microscopy we could demonstrate that the whitish papules were formed by immature collagen with a higher number of fibroblasts, when compared to the adjacent area, according to a previous report. ${ }^{9}$ Moreover, many focal areas of dermalepidermal cleavage could be seen.

Transmission electron microscopy also showed some areas of focal cleavage, which occurred under the lamina densa. Similarly to what was seen with light microscopy, the dermal component of the papu- le is formed by isolated collagen fibers. In addition, an amorphous material was also observed, probably a secondary dermal proliferative phenomenon, as described in another case of PAP-EB.

Although this condition has been reclassified as generalized DDEB, it is important to recognize it as a variant of $\mathrm{EB}$, since the most important cutaneous findings are generalized papules and not blisters and erosions as in others forms of EB. ${ }^{8}$

\section{REFERENCES}

1. Spinelli LP, Orofino RR, Kac BK, Sodré C, Azulay RD. Epidermólise bolhosa albopapulóide (variante de Pasini). An Bras Dermatol 2003;78:459-63.

2. Alonso AM, Marinho DEA, Leal MPL. Epidermólise bolhosa albopapulóide (variante de Pasini). Med Cut ILA. 1981;9:307-10.

3. Shenefelt PD, Castellano LM. Successful treatment of albopapuloid epidermolysis bullosa (Pasini `s variant) with pulse topical corticosteroid therapy. J Am Acad Dermatol. 1993;29:785-6.

4. Horn HM, Tidman MJ. The clinical spectrum of dystrophic epidermolysis bullosa. Br J Dermatol. 2002;146:267-74.

5. Kon A, Nomura K, Pulkkinen L, Sawamura D, Hashimoto I, Uitto J. Novel glycine substitution mutations in COL7A1 reveal that the Pasini and Cockayne-Touraine variants of dominant dystrophic epidermolysis bullosa are allelic. J Invest Dermatol. 1997;109:684-7.

6. Jonkman MF, Moreno G, Rouan F, Oranje AP, Pulkkinem L, Uitto J. Dominant Dystrophic Epidermolysis Bullosa (Pasini) caused by a novel substation mutation in the type VII collagen gene (COL7A1). J Invest Dermatol. 1999;112:815- 7.

7. Mellerio JE, Salas-Alanis JC, Talamantes ML, Horn H, Tidman MJ, Ashton GH, et al. A recurrent glycine substation mutation, G2043R, in the type VII collagen gene (COL7a1) in dominant dystrophic epidermolysis bullosa. $\mathrm{Br} J$ Dermatol. 1998;139:730-7.
8. Fine JD, Eady RA, Bauer EA, Bauer JW, Bruckner-Tuderman L, Heagerty A, et al. The classification of inherited epidermolysis bullosa $(\mathrm{EB})$ : Report of third international consensus meeting on diagnosis and classification of EB. J Am Acad Dermatol. 2008;58:931- 50.

9. Nomura K, Umeki K, Sawamura D, Hashimoto I. Dominant dystrophic epidermolysis bullosa albopapuloidea Pasini -- ultrastructural observations of albopapuloid lesions and a type VII collagen DNA polymorphism study of a family. Acta Derm Venereol. 1997;77:277-80.

\author{
MAILING ADDRESS: \\ Dr. Hiram Larangeira de Almeida Jr. \\ Rua Barroso 1202 \\ 96010-280 Pelotas, RS - Brazil \\ Phone: +55 5332787582 Fax: +55 5332783909 \\ E-mail: hiramalmeidajr@hotmail.com
}

How to cite this article: Almeida Jr HL, Nudelmann L, Rocha NM, Castro LAS. Light and transmission electron microscopy of generalized dystrophic epidermolysis bullosa (Pasini's albopapuloid subtype). An Bras Dermatol. $2012 ; 87(2): 285-7$. 